\title{
Improving Secondary School Students' Attitude towards Geography through Physical and Virtual Laboratories in North Central Nigeria
}

\author{
Oluwole Caleb Falode ${ }^{1}$, Hussaini Usman ${ }^{2}$, Emeka Joshua Chukwuemeka ${ }^{1 *}$, Asabe Hadiza Mohammed ${ }^{3}$
}

\author{
${ }^{1}$ Department of Educational Technology Federal University of Technology, Minna, Niger State, NIGERIA \\ ${ }^{2}$ Niger State Teacher Professional Development Institute, Minna, Niger State, NIGERIA \\ ${ }^{3}$ Department OF Educational Technology, Niger State College of Education, Minna, Niger State, NIGERIA \\ *Corresponding Author: emekac.joshua@gmail.com
}

Citation: Falode, O. C., Usman, H., Chukwuemeka, E. J., \& Mohammed, A. H. (2020). Improving Secondary School Students' Attitude towards Geography through Physical and Virtual Laboratories in North Central Nigeria. Pedagogical Research, 5(4), em0074. https://doi.org/10.29333/pr/8463

\section{ARTICLE INFO}

Received: 9 May 2020

Accepted: 17 Jul. 2020

\begin{abstract}
This study investigated the effects of Physical and Virtual Laboratories on the Attitude of secondary school students' attitude towards learning Geography in North Central Nigeria. The study adopted a quasi-experimental research design. The sample size of the research consisted of 768 students from 12 secondary schools in North Central zone of Nigeria. Four secondary schools from each of the three sampled states in the zone were purposively chosen and randomly assigned to research groups: experimental group I (Physical Laboratory), experimental group II (Virtual Laboratory) and control group (Lecture Method). A 20 - item research instrument titled Questionnaire on Attitude of Students towards Geography (QASG) was used for data collection in this study. Cronbach alpha's formula was employed to ascertain the reliability coefficient of QATG and it yielded 0.70 . The data collected were analysed using descriptive statistics of Mean and Standard Deviation and inferential statistics of Analysis of Variance (ANOVA). The null hypotheses were tested at 0.05 level of significance. The results of the study revealed that physical and virtual laboratories enhanced secondary school students' attitude towards geography better than lecture method and it was therefore recommended that these laboratories should be embraced as teaching strategies for teaching geography concepts in secondary schools in order to improve students' attitude towards the subject.
\end{abstract}

Keywords: attitude, geography, physical laboratory, virtual laboratory, lecture method

\section{INTRODUCTION}

The revolution in digital technology experienced in the 21st century has brought about innovations in classroom teaching and learning. Today, the use of technology tools in teaching and learning is bringing significant changes in ways teachers conceive, organize instruction, and evaluate their students as well as ways in which learners learn. Similarly, advances in educational technology have transformed systems of communication and lesson ideas; teachers' professional development and expedite resourcefulness; learning resources, and learning efficiency (Falode et al., 2015; Mohammed, 2017; Smith, 2015). Thus, the use of modern technologies such as the virtual platforms will not only help teachers to be efficient but will equally help students to learn better and faster thereby improving the quality of learning (Mahya, 2017).

A virtual laboratory is one of the virtual platforms that are increasingly used by educators in response to a perceived demand for more flexible delivery modes that will complement in-class teaching and learning. Virtual laboratories are perceived by Falode (2014), Chaurura and Chuma (2015) as an interactive laboratory setting without actual laboratory equipment, intended for creating and performing replicated experiments. Similarly, Ratamun and Osman (2018) considered virtual laboratories as a computer-assisted instruction through the incorporation of computer applications to perform laboratory activities. Virtual classrooms enable more effective laboratory teaching and learning practices by allowing students to take greater control over their learning experiences (Falode, 2014). This is because it offers a powerful range of tools with flexible and attractive interface, and ubiquitous learning domain to promote more active participation (Subramaniam \& Kandasamy, 2011). Therefore, educators may use it to complement the physical laboratories in impart attitudes, thought processes, problem-solving skills, practical skills, and a whole range of other underlying skills that are not made explicit or at least not embedded when other methods of teaching are employed.

Like the virtual laboratories, the physical laboratories equally can make teaching and learning real, which promotes the greatest cognitive efficiency (Bower, 2006). Russell and Weaver (2008) opined that physical or science laboratories are specifically designed with certain goals, which include enhancing the understanding of scientific concepts, interests and motivations, 
practical skills, and problem-solving abilities. Also, Usman et al. (2019) viewed physical laboratory as a place where students develop scientific thinking, conducts scientific investigations, and obtain knowledge of physical principles and experimental techniques through the usage of equipment at various levels of education. Bower (2006) noted that it is the many aspects of general good teaching and learning practices from the face-to-face delivery system that was directly transferable according to the mechanics of the virtual classroom environment. Hence, the use of a laboratory in teaching subjects like Geography cannot be underestimated.

As a science of the earth, geography has continually played a substantial role in the general development of nations. Geography is taught in schools to offer learners a sound knowledge of their immediate environment and develop in them the ability to comprehend and give details of natural occurrence. The pedagogical approach use for the delivery of geography curriculum in Nigeria is anchored on the constructivism theory of learning as it promotes social and communication skills by creating a classroom environment that emphasizes collaboration and exchange of ideas.

Hence, researchers like Sofowora and Egbedokun (2010) advocated for a change in geography instructional delivery modes. This makes the use of virtual and physical laboratories paramount in teaching Geography in Nigerian schools. Teachers' use of virtual laboratories will specifically help to cultivate students' positive attitudes towards learning subjects like geography in Nigerian schools.

Nigeria currently operates 9-3-4 system of education; the first 9 years is dedicated to basic education That is, six years for lower basic/primary education; and 3 years for upper basic education), which culminates in the Basic Education Certification Examination (BECE). The following three years are for a senior secondary school schooling, which is concluded with the senior school certificate examination (SSCE). Generally, two categories of examinees (internal/school and private/external candidates) take the SSCE every year. The internal candidates are the students in their third year in the senior secondary school (SSIII) who take their examination in May/June. The external candidates are not in the school system and are composed majorly of those who take the examinations around November/December to make up for their deficiencies in certain subjects. The last stage of the Nigerian education system takes at least 4 years of study to earn a Bachelor's degree, with some courses taking up to 6 years of study. There are three major SSCE conducting bodies in Nigeria namely; West African Examination Council (WAEC); National Examination Council (NECO); National Business and Technical Examination Board (NABTEB).

The recent re-organization and the improvement of the Geography educational module and recent change from 6-3-3-4 to 63-9 system of education at the Senior Secondary levels remarkably resulted to current and actual transformation in the state of geography education in Nigeria, subsequent from these, educators are more concerned simply with turning out students who are mounded with certainties and relevant expressions in Geography (Sofowora \& Agbedokun, 2010). Presently, Geography is one of the science subjects taught at the senior secondary school level of education in Nigerian schools. Aside from it being offered at the senior secondary schools (SSS) for Senior Secondary School Certificate Examination, it is a subject taught at the tertiary level and it links with a few other school subjects to make an individual an expert. The West African School Certificate Examination Council (WAEC) has been assessing its syllabi over the course of the years to reflect contemporary issues, react to open issues, and adjust to realities of time (Aderogba \& Ogunnowo, 2010). The breakdown of the content of the Geography syllabus is grouped into four areas specifically: Elements of Practical Geography (Map Work); Physical Geography; Human Geography; Regional Geography (Sofowora \& Agbedokun, 2010). The National Examination Council (NECO, 2004) likewise prepared its syllabus nearly to the WAEC's, this enhances the attitude of students towards the subject and eventually shows them areas of interest in Geography syllabus as provided by the two national examination bodies and actualized by schools and universities (Usman, 2016).

Attitude is often seen as established conduct or mode of performance, which it has to do with the interpretation of emotion or belief (Issa, Bashorun, Mubashir, \& Adewusi, 2010). Bowen and Richman (2000) conceptualized attitude as a mix of an individual's surveyed decision around a given element. Attitude is one of those variables that can influence performance. A study undertaken by Keter et al. (2016) established that one way of improving students' attitudes towards sciences is through the use of laboratory apparatus present in physical laboratories as well as in simulations present in virtual laboratories. Study by Zacharia (2003), Tunçok (2010), and Tella and Bashorun (2012) investigated students' attitudes towards school subjects when computer is used as medium of instruction. Their findings revealed that computer assisted instructions resulted to students' positive attitude towards the subjects and content taught. Sundra (2014) addressed the effectiveness of a virtual science and traditional laboratory in science subject in terms attitudes, and self-efficacy of students in University College, students expressed positive attitudes in terms of liking as well as interests in performing experiments in virtual laboratories. The result of his studies was significant, this indicates that virtual laboratories may be a substitute for traditional laboratories to some extent, and may play a vital role in science courses. Falode et al. (2016) investigated the effectiveness of computer simulation instruction on the attitude of geography students towards map reading in Bida, Nigeria. The findings of the study revealed that the attitude of students towards map reading was significantly improved at posttest. While, Ratamun, and Osman (2018) compared the effectiveness of Virtual Laboratory and Physical Laboratory in students' attitude towards science subject. The two-way ANCOVA analysis showed that the effectiveness of group on the post attitude towards science subject was not significant. It concluded that the level of students' attitude towards science is same when experiment is done in Virtual or Physical Laboratories.

In their separate studies, Tabassum (2004), Gambari and Mogbo (2005), Onasanya et al. (2006), and Falode (2016) revealed that gender does not influence students' attitude, some revealed that gender does influence attitude in favour of male students as revealed by Ifamuyiwa (2004) and Iwendi (2009) while some also go in favour of female students as revealed by Mitra and Steffeensmeier (2000), Jacobs and Osgood (2002), Anagbogu and Ezeliora (2007), and Iwendi (2009). 


\section{STATEMENT OF THE RESEARCH PROBLEM}

Despite the importance attached to Geography as stated in the National Policy on Education, previous researches by Falode et al. (2015), Falode et al. (2016), Amosun (2016), Usman (2019), and Eze (2020) pertaining students' outcomes in Geography have indicated to unsatisfactory, poor and discouraging performance of Nigerian secondary school students.

The findings of these research further reveal that students' poor attitude towards the subject is one of the factors responsible for the failure in Geography. Additionally, West African Examination Council's examiners WAEC, (2008), (2013); and (2018) reports in recent years, had linked inadequate explanation of points, inadequate preparation and poor presentation of geographical features and concepts that were required to be taught practically thereby making its concepts highly theoretical and difficult for the students to comprehend which leads to the students' failure in the subject. The records in Appendix A illustrates WAEC chief examiners' report, the record specifically depicts candidates' area of weaknesses in Geography. The weaknesses are not unconnected with the poor attitude of students towards the subject as aforementioned by researchers.

This has become a source of concern for all stakeholders in the Nigerian education system. Thus, the search for effective strategies that could improve students' poor attitude towards Geography and enhance the teaching and learning of the subject in schools. Hence, the need for this study.

\section{RESEARCH QUESTIONS}

The following research questions were raised for the study:

1. Would there be any difference in the mean scores of students' attitudes towards Geography when exposed to a physical laboratory, virtual laboratory, and lecture method?

2. Would there be any difference in the mean scores of male and female students' attitude to Geography after exposure to a virtual laboratory?

3. Would there be any difference in the mean scores of male and female students' attitude towards Geography after exposure to a physical laboratory?

\section{HYPOTHESES}

The following null hypotheses were tested in the study:

$\mathbf{H O}_{\mathbf{1}}$ There is no significant difference in the mean scores of students' attitude towards Geography after exposure to physical laboratory, virtual laboratory and lecture method.

$\mathbf{H O}_{2}$ There is no significant difference in the mean scores of male and female students' attitude towards Geography after exposure to virtual laboratory.

$\mathbf{H O}_{3}$ There is no significant difference in the mean scores of male and female students' attitude towards Geography after exposure to physical laboratory.

\section{METHODOLOGY}

The study adopted a pre-test, post-test non-randomized quasi-experimental research design and used an intact class. The population for this study was made up of the entire Senior Secondary school students of the 2018/2019 session in the NorthCentral geopolitical zone of Nigeria. Twelve (12) co-educational public senior secondary schools in North-Central Geopolitical Zone of Nigeria (Niger, Kwara, Kogi, Benue, Plateau and Nasarawa states and the Federal Capital Territory, Abuja) were used for the study.

The states in the zone were clustered into three regions A, B, and C. Out of the three regions, one state was selected from each region using a simple random sampling technique. Thereafter, three co-educational schools were purposively chosen from each of the three states at random and were assigned to experimental group I (Physical Laboratory: PL), experimental group II (Virtual Laboratory: VL), and control group (Lecture Method: LM). The reason for the purposive sampling of the schools is to select schools with common conditions such as manpower, gender composition, and exposure to the use of computer and geography laboratories.

The target population was 768-year two Geography students in senior secondary school (SSII). The choice of year two senior secondary school class was based on the fact that the class was the most stable one as at the time the study was being conducted as they were not preparing for any examination which could jeopardize the outcome of this study. Also, the concepts of geography taught was meant for the class. The sample size was 768 Senior Secondary School Geography students in class II. This sample which is made up of students that falls between 14-17 age group comprises of (Experimental Group I; 242= Males= 142, Females= 95); (Experimental Group II; 269= Males= 159, Females= 110); (Control Group; 257= Male= 185, Female= 72).

The geography concepts taught were Contour representation of landforms, Gradient, and relief features, the content was selected because they are difficult concepts and fell in the SSII class syllabus. The Virtual Laboratory Package (VLP) was developed 
Table 1. Mean, standard deviation and ANOVA analysis of scores on the attitude of students in Experimental Groups I and II and the Control Group

\begin{tabular}{|c|c|c|c|c|c|c|}
\hline \multirow{2}{*}{ Group } & \multirow[t]{2}{*}{$\mathbf{N}$} & \multicolumn{2}{|c|}{ Pre-test } & \multicolumn{2}{|c|}{ Post-test } & \multirow{2}{*}{ Mean Difference } \\
\hline & & $\overline{\boldsymbol{X}}$ & SD & $\overline{\boldsymbol{X}}$ & SD & \\
\hline Experimental Group I & 242 & 54.69 & 10.63 & 81.12 & 9.201 & 26.43 \\
\hline Experimental Group II & 269 & 51.02 & 11.47 & 77.97 & 11.484 & 26.95 \\
\hline \multirow[t]{2}{*}{ Control Group } & 257 & 48.25 & 11.31 & 72.97 & 11.670 & 24.72 \\
\hline & Sum of Squares & Df & Mean Square & F-Value & P-Value & \\
\hline Between Groups & 8486.031 & 2 & 4243.015 & 35.840 & .000 & \\
\hline Within Groups & 90567.051 & 765 & 118.388 & & & \\
\hline Total & 99053.082 & 767 & & & & \\
\hline
\end{tabular}

using Adobe Flash Professional and ActionScript 3.0. In the Physical laboratory setting, students have direct physical involvement with models, charts, picture maps, and the teacher to study the observable fact and experience experimental practices. While the students assigned to the control group have direct contact with the teacher and instructional materials such as diagrams, topographic maps, and textbooks to teach the geography concepts. The time allocated to classes to deliver the lesson in each group (experimental I, II and control group) is 1 hour 30 minute

The research instrument that was used for data collection was a Questionnaire on the Attitude of Students towards Geography (QASG). It was divided into two parts, part one sought for bio-data of respondents, while part two consisted of 20 items on the attitude of students. The 4-point Likert type of response of Strongly Agree (SA), Agree (A), Disagree (D), Strongly Disagree (SD) was adopted in which the items were scored based on the weight of each point - 4, 3, 2, 1 for SA, A, D, SD respectively (as shown in the Appendix). The research instrument was appropriately validated by software design experts, educational technology professionals, behavioral psychologists, and geography teachers. The reliability of the instrument was determined through a pilot study that was conducted using SSII geography students from one co-educational school within the study area but outside the schools sampled for the main study. The data obtained were analyzed using Cronbach alpha's formula, and an internal consistency coefficient value of 0.70 was obtained. This indicates that the instrument is reliable.

For the main study, after the administration of the instruments to the sampled participants, data collected were analyzed using descriptive statistics (Mean and Standard Deviation) and inferential statistics (Analysis of Variance) with the aid of Statistical Package for Social Sciences (SPSS) version 23.0 and the significance or otherwise of the stated null hypotheses was ascertained at 0.05 alpha level. Besides, Scheffe Post-hoc test was used to determine the location of the differences within the three groups.

\section{RESULT}

Research Question 1: Would there be any difference in the mean score of students' attitudes towards Geography when exposed to physical laboratory, virtual laboratory, and lecture method?

$\mathbf{H O}_{\mathbf{1}}$ There is no significant difference in the mean scores of students' attitudes towards Geography after exposure to physical laboratory, virtual laboratory, and lecture method.

Table 1 shows the mean and standard deviation and ANOVA analysis of students' attitudes when taught Geography through experimental I (physical laboratory), Experimental Group II (virtual laboratory), and those taught using lecture methods in the Control Group at pretest and post-test. From the table, it can be noted that the mean and standard deviation scores at pre-test and post-test for the experimental group I (Physical Laboratory) are $X=54.69, S D=10.63$, and $X=81.12, S D=9.201$ respectively. This gives the mean gain of 26.43 in favor of the post-test. Similarly, the mean attitude score and standard deviation at pre-test and post-test for the experimental group II (Virtual Laboratory) are $X=51.02, S D=11.47$, and $X=77.97, S D=11.848$ respectively. This gives the mean gain of 26.94 in favor of the post-test. On the other hand, the mean and standard deviation scores at pre-test and post-test for the control group (lecture methods) are $X=48.25, S D=11.31$, and $X=72.97, S D=11.67$ respectively. This gives the mean gain of 24.72 in favor of the post-test. On the general note, Table 1 recorded the mean gain at different levels of administration of the test to the three groups.

Furthermore, the table also shows that there was a significant difference in the attitude scores of students in the three intervention groups at post-test $\left(F_{(2,765)}=35.840, P=.000, P<0.05\right)$. Therefore, hypothesis one was rejected. That is, there was a significant difference in the mean attitude scores of students towards Geography after being taught using physical, virtual laboratories, and Lecture method. To determine the location of the differences observed, Sheffe post-hoc analysis was carried out and the result of the comparison is presented in Table 2.

Table 2 shows the Scheffe post-hoc analysis of attitude scores of students in Experiment Groups I and II, and the Control Group. The table indicates that a significant difference exists between the attitude scores of students in the experimental group I and experimental group II (mean difference $=3.15$ ) in favour of experimental group 1. It also shows that significant difference exists between the attitude scores of students in experimental group I and control group (mean difference $=8.15$ ) in favour of experimental group 1. Also, the table shows that significant difference exists between experimental group II and control group (mean difference $=5.00$ ) in favour of experimental group II. The implication is that physical laboratory improved the attitude of students better than virtual laboratory and lecture method while virtual laboratory improved students' attitude towards geography better than lecture method. 
Table 2. Scheffe post-hoc comparison of mean differences of student scores in Experimental Group I, II and the Control Group

\begin{tabular}{cccc}
\hline Treatment & Experimental I & Experimental II & Control \\
\hline Experimental I & - & $3.15^{\star}$ & $8.15^{\star}$ \\
\hline Experimental II & $-3.15^{\star}$ & - & $5.00^{\star}$ \\
\hline Control & $-8.15^{\star}$ & $-5.00^{\star}$ & - \\
\hline *: Significant at 0.05 alpha level & & &
\end{tabular}

Table 3. Mean, standard deviation and ANOVA analysis of scores on male and female students' attitude towards Geography using virtual laboratory

\begin{tabular}{|c|c|c|c|c|c|c|}
\hline \multirow{2}{*}{ Group } & \multirow[t]{2}{*}{$\mathbf{N}$} & \multicolumn{2}{|c|}{ Pre-test } & \multicolumn{2}{|c|}{ Post-test } & \multirow{2}{*}{ Mean Difference } \\
\hline & & $\overline{\boldsymbol{X}}$ & SD & $\bar{X}$ & SD & \\
\hline Male & 159 & 45.02 & 10.375 & 79.26 & 10.871 & 34.24 \\
\hline \multirow[t]{2}{*}{ Female } & 110 & 44.15 & 11.041 & 76.12 & 12.123 & 31.97 \\
\hline & Sum of Squares & Df & Mean Square & F-Value & P-Value & \\
\hline Between Groups & 639.937 & 1 & 639.937 & 4.923 & 0.207 & \\
\hline Within Groups & 34573.824 & 266 & 129.977 & & & \\
\hline Total & 35213.761 & 268 & & & & \\
\hline
\end{tabular}

Table 4. Mean, standard deviation and ANOVA analysis of scores on male and female students' attitude towards Geography using physical laboratory

\begin{tabular}{|c|c|c|c|c|c|c|}
\hline \multirow{2}{*}{ Group } & \multirow[t]{2}{*}{$\mathbf{N}$} & \multicolumn{2}{|c|}{ Pre-test } & \multicolumn{2}{|c|}{ Post-test } & \multirow{2}{*}{ Mean Difference } \\
\hline & & $\bar{X}$ & SD & $\bar{X}$ & SD & \\
\hline Male & 147 & 73.45 & 10.375 & 81.05 & 9.203 & 7.6 \\
\hline \multirow[t]{2}{*}{ Female } & 95 & 67.56 & 11.041 & 80.22 & 9.247 & 12.66 \\
\hline & Sum of Squares & Df & Mean Square & F-Value & P-Value & \\
\hline Between Groups & 1.568 & 1 & 1.568 & .018 & .892 & \\
\hline Within Groups & 20487.971 & 241 & 85.012 & & & \\
\hline Total & 20489.539 & 242 & & & & \\
\hline
\end{tabular}

Research Question 2: Would there be any difference in the mean scores of male and female students' attitude to Geography after exposure to virtual laboratory?

$\mathbf{H O}_{\mathbf{2}}$ There is no significant difference in the mean attitude scores of male and female students towards Geography after being exposed to virtual laboratory.

Table 3 shows the mean attitude scores and standard deviation of male and female students taught Geography using Virtual laboratory at pretest and post-test levels. From the table, it can be deduced that the mean and standard deviation scores at pretest and post-test for the male students are $X=45.02, S D=10.375$, and $X=79.26, S D=10.871$ respectively. This gives the mean difference of 34.24 in favor of the post-test. Similarly, the mean attitude score and standard deviation at pre-test and post-test for the female students are $X=44.15, S D=11.041$, and $X=76.12, S D=12.123$ respectively. This gives the mean gain of 31.97 in favor of the post-test.

As a result of this identified difference in mean attitude scores, hypothesis two was tested at 0.05 level. The table indicates that there was no significant difference between male and female post attitude scores of students after being exposed to a virtual laboratory $\left(\mathrm{F}_{(1,266)}=4.923 \mathrm{P}=.027 \mathrm{P}>0.05\right)$. Based on this, hypothesis two was retained. Therefore, the result revealed that there was no significant difference between the attitude of male and female students taught Geography using a virtual laboratory.

Research Question 3: Would there be any difference in the mean scores of male and female students' attitudes towards Geography after being exposed to physical laboratory?

$\mathbf{H O}_{3}$ There is no significant difference in the mean attitude scores of male and female students towards Geography after exposed to a physical laboratory.

Table 4 shows the mean attitude scores and standard deviation of male and female students taught Geography using physical laboratory at pretest and post-test. From the table, it can be seen that the mean and standard deviation scores at pre-test and post-test for the male students are $X=73.45, S D=10.375$, and $X=81.05, S D=9.203$ respectively. This gives the mean difference of 7.6 in favor of the post-test. Similarly, the mean attitude score and standard deviation at pre-test and post-test for the female students are $X=67.56, S D=11.041$, and $X=80.22, S D=9.247$ respectively. This gives the mean gain of 12.66 in favor of the post-test.

The table indicates further that that there was no significant difference between male and female post attitude scores of students after being exposed to physical laboratory $\left(\mathrm{F}_{(1,241)}=018 \mathrm{P}=.892 \mathrm{P}>0.05\right)$. Based on this, hypothesis 3 was retained. Therefore, the result revealed that there was no significant difference between the attitude of male and female students taught Geography using physical laboratory.

\section{DISCUSSION OF FINDINGS}

The results of this study in Table 1 indicated that the post-test mean attitude score (81.12) of experimental group I (Physical Laboratory) is higher than the post-test mean attitude score (77.97) of experimental group II (Virtual Laboratory) while the control 
group had the least post-test mean attitude score of 72.92. This is further confirmed by ANCOVA result in Table 2 which shows that the attitude scores of experimental I, II, and control groups differ significantly. The result indicated that treatment using Physical and virtual laboratories improved students' positive attitude towards Geography. The justification for this finding is because students naturally show good dispositions towards learning activities that make them active participants (such as physical and virtual laboratories) unlike the lecture method where they are passive during the teaching and learning process, hence the noticeable difference in their attitude towards the subject when exposed to the different strategies.

The result of our study is in agreement with the earlier finding of Falode et al (2016), who investigated the effectiveness of computer simulation instruction on the attitude of geography students towards map reading. The study revealed that the attitude of students towards map reading was significant. Also, the finding of this study is in line with the earlier result reported by Zacharia (2003), Tuncok (2010), and Tella and Bashorun (2012) who in their different studies found out that students have positive attitude to science courses. Disagreeing with the finding of this study is Ratamun, and Osman (2018), who compared the effectiveness of Virtual Laboratory and Physical Laboratory in students' attitude towards science subject. The result showed that the effectiveness of group on the post attitude towards science subject was not significant.

The post means attitude scores for both males 81.05 and female 80.22 in a physical laboratory and male 79.26 and female 76.12 in virtual laboratory improve significantly. This is further confirmed by ANOVA analyses which show that there was no significant difference in the attitude of male and female geography students when exposed to physical and virtual laboratories. The similarity in the attitude of male and female geography students after being exposed to physical and virtual laboratories could be the result of the fact that students have positive interest towards working and performing series of activities in an environment that emphasizes collaboration, social interaction and exchange of ideas.

The result therefore, is in agreement with the finding of Falode (2016) the result revealed that there was no significant difference in between male and female students when taught map reading using computer simulation instruction. The finding also concurs with the finding of Tabassum (2004); Onasanya, Daramola and Asuquo (2006); and Gambari and Mogbo (2006) who in their different studies found and reported that gender has no influence on the attitude of students in computer based learning.

Contrary to the finding of this study, Mitra and Steffeensmeier (2000) found and reported that female students have less positive attitude towards computer instructional packages compare to their male counterparts.

\section{CONCLUSION}

Geography is regarded as one of the core subjects in Nigerian secondary school education. Excellent academic achievement of students in the subject is an indication of the actualization of the objectives for its inclusion in the curriculum. This can only be brought about when students' have positive attitudes towards the subject. This study has revealed that physical and virtual laboratories better-improved students' attitudes towards geography and their adoption in teaching and learning of the subject will lead to the improved academic performance of students. It can only be concluded that gender may or may not influence students' attitude towards Geography when exposed to the two strategies as observed in this study.

\section{RECOMMENDATIONS}

Based on the findings that emanated from this study, the following recommendations are proffered:

1. Physical and virtual laboratories should be embraced as better strategies for teaching geography concepts in our senior secondary schools because they have proven to improve students' attitudes towards geography.

2. Teachers should be encouraged and trained to be familiar with the use of current approaches, especially in the use of modern laboratories. This will enable them to appreciate the use of recent innovative strategies in teaching and learning in the laboratory environment and further improve the attitude of students towards geography irrespective of their gender.

3. The Federal and State Ministries of Education and other stakeholders such as Nigerian Teachers Institute (NTI), Nigerian Education and Research Development Council (NERDC), Non-Governmental Organisations (NGOs), United Nations International Children's Emergency Fund (UNICEF) and United Nations Scientific and Cultural Organisation (UNESCO) should ensure that there is availability of both physical and virtual laboratory, this will encourage both teachers and students' attitude to use the facilities during geography class.

\section{REFERENCES}

Amosun, P. A. (2016). Why Nigerian geography teachers scarcely and scantly teach map reading and why students are scared of it. African Educational Research Journal, 4(2), 42-48.

Awofala, A. O., Arigbabu, A. A., \& Awofala, A. A. (2013). Effects of framing and team assisted individualised instructional strategies on senior secondary school students' attitudes towards mathematics. Acta Didactica Napocensia, 6(1), 1.

Bhowmik, M., \& Banerjee (Roy), B. (2016). A study on relationship between achievement in mathematics and attitude towards mathematics of secondary school students. International Journal of Education and Multidisciplinary Studies, 4(3), $402-408$. https://doi.org/10.21013/jems.v4.n3.p7 
Bowen, L. \& Richman, M. (2000): middle school student's perceptions of the school environment. Journal of Social Work in Education, 13(2), 69-82. https://doi.org/10.1093/cs/22.2.69

Chaurura, P. Chuma, K. (2015) Virtual Laboratories- a Solution for Tertiary Science Education In Botswana European Journal of Logistics Purchasing and Supply Chain Management, 3(1), 29-32.

Eze, E. (2020). Sociographic analysis of climate change awareness and pro-environmental behavior of secondary school teachers and students in Nsukka Local Government Area of Enugu State, Nigeria. International Research in Geographical and Environmental Education, 29(1), 89-105. https://doi.org/10.1080/10382046.2019.1657683

Falode, O. C. (2014). A BATES"ACTIONS" evaluation of virtual physics laboratory package for senior secondary school students in Nigeria (Unpublished PhD Thesis), Department of Educational Technology, University of Ilorin, Nigeria.

Falode, O. C. Usman, H. Ilobeneke, S. C, Mohammed, H. A, Godwin, A. J., \& Jimoh, M. A. (2016). Improving secondary school geography students' attitude towards map reading in bida, Niger State. Bulgarian Journal of Science and Education Policy, 10(1), 149-150.

Falode, O. C. Usman, H. Sobowale, F. M. Folarin, M. E \& Saliu R. M. (2015). Effect of computer simulation instructional package on secondary school Geography students' achievement in Map Reading in Bida, Niger State, Nigeria. $3^{\text {rd }}$ Annual International Conference of School of Science and Technology Education, Federal University of Technology Minna.

Federal Republic of Nigeria, (2009). National Policy on Education. Lagos: Federal Government Press.

Ho, W. C. (2009). The Role of Multimedia Technology in a Hong Kong Higher Education Music Program. Visions of Research in MUSIC Education, 13. Retrieved from http://www-usr.rider.edu/ vrme/v13n1/Vision/Ho.finalfaedits.01.15.09.pdf

Ifamuyiwa, A. S. (2004). The predictive validity of junior secondary mathematics on senior secondary mathematics, further mathematics and physics. Science Teacher Association of Nigeria 45th Annual Conference.

Issa, A. O., Bashorun, M. T., Mubashir, A. L., \&_Adewusi, E. T. (2010). Attitudes of undergraduate students of the University of Ibadan towards computerized services at the Kenneth Dike library. Journal of Library and Information Science, 7(1\&2), 18-33.

Iwendi, B. C. (2009). The influence of gender and age on the mathematics achievement of secondary school students in Minna metropolis, Niger State (Unpublished - MTech. Thesis). Minna: Federal University of Technology

Jacobs, J. E., \& Osgood, D. W. (2002). The use of multi-level modeling to study individual change and context effects in achievement motivation. In: P. R. Pintrich \& M. L. Maehr (Eds.), New directions in measures and methods (pp. 277-318). Amsterdam: Elsevier.

Keter, J. K., Wachanga, S. W., \& Anditi, Z. O. (2016). Effect of Gender on Motivation in Chemistry Lessons When Students Are Taught through Computer Based Cooperative Mastery Learning (CBCML) in Bomet County, Kenya. Journal of Educational Policy and Entrepreneurial Research, 3(11), 24-35.

Mitra, A., \& Steffensmeier, T. (2000). Changes in student attitudes and student computer use in a computer-enriched environment. J. Res. Computing Educ., 32, 417-433. https://doi.org/10.1080/08886504.2000.10782289

Mohammed, H. A. (2017). Effects of computer simulation instructional package on primary school pupils"motor skills development and interest towards physical education in niger state, Nigeria (Unpublished Phd Thesis), Department of Educational Technology, Federal University of Technology Minna, Nigeria.

National Examination Council, (2009 \& 2010). June/July. Chief Examiner's Report. Lagos.

Onasanya, S. A., Daramola F. O., \& Asuquo, E. N. (2006). Effect of computerassisted instructional package on secondary school students' performance in introductory technology in Ilorin, Nigeria. Nigeria Journal of Education Media \& Technology, 12(2), 98107.

Ratamun, M. M., \& Osman, K. (2018) The Effectiveness comparison of virtual laboratory and physical laboratory in nurturing students' attitude towards chemistry. Creative Education, 9, 1411-1425. https://doi.org/10.4236/ce.2018.99105

Russel, A. \& Weaver, R. (2008). Student Perception of the Purpose and Function of the Laboratory in Science: A Grounded Theory Study. internation journal of scholarship of teaching and learning, 4(2), 25-26. https://doi.org/10.20429/ijsotl.2008.020209

Smith, G. W. (2015). Combining physical and virtual_laboratories: effects of perceptional features of science laboratory enviroment on learning-conceptions (Unpublished PhD Thesis), Educational Psychology Department, University of Wisconsin-Madison, United States.

Sofowora, O. A., \& Egbedokun, A. (2010). An Empirical Survey of Technology Application in Teaching Geography in Nigerian Secondary Schools. Ethiopian Journal of Environmental Studies and Management, 3(1), 67-68. https://doi.org/10.4314/ejesm.v3i1.54400

Tella, A., \& Bashorun, M. T. (2012). Attitude of undergraduate students towards computer-based test (CBT): a case study of the University of Ilorin, Nigeria. International Journal Information \& Communication Technology Education, 8(2), 33-45. https://doi.org/10.4018/jicte.2012040103

Tunçok, B. (2010). A case study: students' attitudes towards computer assisted learning, computer assisted language learning and foreign language learning (MA thesis), Ankara: Middle East Technical University.

Usman, H. Alabi, T. O. Falode O. C., \& Muhammed, B. Y (2019). Effects of Physical and Virtual Laboratories on the Achievement of Secondary School Geography Students in North Central Nigeria. International Journal of Education and Educational Research, 2(2), 3.

West African Examination Council. (2008, 2009, 2011, 2012). June/July. Analysis of performance of candidate in Geography result. Lagos. 
West African Examination Council. (2008, 2010, 2013, 2018). June/July. Analysis of performance of candidate in Geography result. Lagos.

Zacharia, Z. (2003). Beliefs, attitudes, and intentions of science teachers regarding the educational use of computer simulations and inquiry-based experiments in physics. Journal of Research. Science Teaching, 40, $792-823$. https://doi.org/10.1002/tea.10112 


\section{APPENDIX A}

The tables below illustrates WAEC Chief Examiner's Reports Depicting Candidates' areas of weakness in Geography.

\begin{tabular}{lll}
\hline Students Weakness & May/June reported years & Nov./Dec. reported years \\
\hline Inadequate explanation of points. & $2008,2009,2010,2011,2012,2013,2014$, & 2008, 2009, 2011, 2014, 2017, 2018 \\
& $2015,2016,2017,2018$ & \\
\hline Inadequate preparation & $2008,2009,2010,2011,2012,2013,2014$, & $2008,2009,2011,2012$ \\
& $2015,2016,2017,2018$ & \\
\hline Poor, presentation, of geographic features & $2008,2009,2010,2011,2013,2014$. & 2008, 2011, 2012, 2015 \\
\hline
\end{tabular}

\section{APPENDIX B}

\section{Questionnaire on Attitude of Students towards Geography}

Instruction: What is your own opinion is the best answer considering the items listed A - D.

Instruction: Respond by ticking the appropriate answer that describes your opinion in the question?

\section{Section A}

Personal Data:

Name of the School:

Class:

Gender:

Age: $11-15$
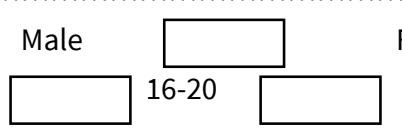

Female

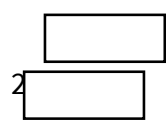

\section{Section B}

1. The virtual laboratory develops the attitude of geography students to the technological world.

2. Geography enables students to link up with important information experiences in the global world.

3. Geography enables students to develop self-concept, self-actualization, and self-reliance.

4. The teaching of the concept (contour representation of landforms) increases students' punctuality in the class.

5. Teaching and learning of concepts (contour representation of landforms) through virtual lab are easily understood by geography students.

6. $\quad$ Effective manipulation of materials is developed when learning through physical and virtual laboratories

7. Learning of physical geography Creates student/ teacher rapport.

8. Students respond vividly to questions in physical geography.

9. Learning through physical and virtual laboratories does not help the teacher to control large classes.

10. It increases student punctuality and participation in the classroom

11. Interaction between students, teachers, and materials during teaching and learning of physical geography is enhanced.

12. The development of teamwork and knowledge-seeking is increased.

13. It is time-consuming.

14. They do like using computer manipulation more than a practical lesson in the laboratories.

15. Physical geography develops the creative thinking and a desire for project work.

16. Interaction with the virtual world during teaching physical geography brings about friendship among students.

17. The relationship between previous knowledge and new knowledge is enhanced in a physical and virtual class.

18. Students develop skills in learning, observation, asking questions thinking, and analyzing results.

19. It encourages students to work on their own and creates in them the mastery of the subject matter.

20. Difficult concepts in physical geography should be stimulated for easy and fast understanding. 